\title{
ОСОБЕННОСТИ ПРЕДЕЛОВ СУДЕБНОГО РАЗБИРАТЕЛЬСТВА ПРИ РАССМОТРЕНИИ УГОЛОВНОГО ДЕЛА СУДОМ С УЧАСТИЕМ ПРИСЯЖНЫХ ЗАСЕДАТЕЛЕЙ
}

\begin{abstract}
Аннотация. Статья посвящена особенностям пределов судебного разбирательства при рассмотрении уголовного дела судом с участием присяжных заседателей. Первая особенность состоит в "разделении» обвинения на части (элементы), подлежащие исследованию с участием присяжных заседателей и исследуемые только после вынесения вердикта. Вторая особенность обусловлена составлением особого процессуального акта - вопросного листа, представляющего собой изложение фактической основы обвинения, а нередко и фактической основы позиции защиты. Следующий круг проблем связан с закрепленной в УПК РФ возможностью сторон ставить перед присяжными частные и альтернативные вопросы, которые могут изменять содержание обвинения. Сложности с соблюдением пределов обусловлены также правом присяжных при вынесении вердикта признавать какие-либо обстоятельства недоказанными, т.е. изменять фактическую сторону обвинения. Завершает статью анализ проблем соответствия формулировки и юридической квалификации преступления в приговоре суда фактическим обстоятельствам, установленным вердиктом присяжных заседателей.

Ключевые слова: юриспруденция, пределы судебного разбирательства, суд присяжных, вердикт, приговор, изменение обвинения, вопросный лист, обвиняемый, обвинение, присяжные заседатели.
\end{abstract}

DOI: $10.7256 / 1729-5920.2014 .5 .7340$

$\mathrm{P}$ азделение компетенции между председательствующим судьей и коллегией присяжных заседателей оказывает существенное воздействие на все аспекты судебного разбирательства в суде присяжных, в том числе и на его пределы.

С одной стороны, в ст. 252, 335, 336 УПК РФ не говорится о каких-либо особенностях действия этого общего условия судебно- го разбирательства в суде с участием присяжных заседателей. Но с другой - особенности судебного следствия и прений сторон в суде присяжных, наличие институтов постановки вопросов присяжным заседателям, вердикта присяжных, этапа обсуждений последствий этого вердикта объективно предопределяют особенности пределов судебного разбирательства в данной форме судопроизводства.

(c) Насонов Сергей Александрович

* Кандидат юридических наук, доцент кафедры уголовно-процессуального права Московского государственного юридического университета имени О.Е. Кутафина (МГЮА)

[sergei-nasonov@yandex.ru]

123995, Россия, г. Москва, ул. Садовая-Кудринская, д. 9.

Статья подготовлена в ходе выполнения поисковой научно-исследовательской работы в рамках реализации ФЦП «Научные и научно-педагогические кадры инновационной России» на 2009-2013 г2. 
Эти особенности проявляются прежде всего в содержании обвинения и образующих его обстоятельств, которые подлежат доказыванию в судебном заседании с участием присяжных заседателей.

Исходя из правила разделения компетенции (ст. 334 УПК РФ), до вынесения присяжными заседателями вердикта по делу стороны не могут исследовать и оценивать в судебном заседании сугубо юридические аспекты обвинения. Этот запрет касается как судебного следствия, прений сторон, так и этапа постановки вопросов присяжным заседателям. Нарушение запрета нередко рассматривается судом второй инстанции как основание к отмене приговора, постановленного на основании вердикта присяжных заседателей.

В практике Верховного Суда РФ уже длительное время проявляется тенденция жесткого разделения вопросов права и факта применительно к пределам судебного разбирательства в суде присяжных.

Так, в определении Верховного Суда РФ от 24.02.1998 отмечалось: «...В суде присяжных коллегия присяжных заседателей принимает участие в исследовании обстоятельств дела и разрешает вопросы только о фракте. Bce правовые и процессуальные вопросы входят в исключительную компетенцию председательствующего судьи и разрешаются без участия присяжных заседателей» ${ }^{1}$.

При рассмотрении дела К. защитник подсудимого, выступая в прениях, сообщила присяжным заседателям следующее: «Было ли у него намерение, которое юридически называется умыслом, своими действиями причинить телесные повреждения человеку, от которых могла наступить смерть, но по не зависящим от него обстоятельствам не наступила? Нельзя упускать из вида, что, возможно, это было не покушение на убийство, а причинение тяжкого вреда здоровью». Отменяя приговор по данному делу, Верховный Суд РФ отметил, что «...суд необоснованно оставил без внимания вышеприведенное выступление адвоката перед коллегией присяжных заседателей относительно наличия умысла и юридической квалификации действий К., которые подлежали рассмотрению без участия присяжных заседателей, а это могло повлиять на их мнение о виновности или невиновности К.»².

Цит. по: Пашин С.А. Становление правосудия. М., 2011. C. 271.

Кассационное определение Судебной коллегии по уголовным делам Верховного Суда РФ от 05.09.2006 № 11-о06-86сп // СПС «КонсультантПлюс».
В соответствии с ч. 5 ст. 339 УПК РФ при составлении вопросного листа не могут ставиться отдельно либо в составе других вопросы, требующие от присяжных заседателей юридической квалификации статуса подсудимого, а также иные вопросы, требующие собственно юридической оценки при вынесении присяжными заседателями своего вердикта. Данное правило также проявление рассматриваемой особенности пределов судебного разбирательства в суде присяжных, его нарушение влечет отмену приговора судом второй инстанции.

Так, Верховный Суд РФ отменил приговор по делу в отношении К., А. и Т., поскольку недопустима постановка вопросов, подлежащих разрешению присяжными заседателями, с использованием юридических терминов. Эти требования закона нарушены председательствующим при составлении вопросного листа по уголовному делу в отношении К., А. и Т. Вопросы № 1, 2, 5, 8, 11, 12, 15, 18, 21, 22, 25, 28 в вопросном листе требовали собственно юридической оценки при вынесении присяжными заседателями своего вердикта, поскольку содержали юридические термины, такие как “организованная группа"

По другому делу Верховный Суд РФ, отменяя приговор, отметил, что «...перед коллегией присяжных заседателей 1 и 2 вопросы сфрормулированы с применением юридических терминов, подлежащие юридической, уголовно-правовой оценке: "унижены честь и достоинство” "в связи с отправлением ей правосудия”, “проявляя неуважение к суду” ${ }^{4}$.

Указанные аспекты обвинения устанавливаются на этапе обсуждения последствий вердикта присяжных заседателей, где проводится вторая часть судебного следствия и прений сторон.

Эта особенность пределов судебного разбирательства в суде присяжных до сих пор является предметом острой дискуссии между сторонниками различных моделей разделения компетенции между присяжными заседателями и председательствующим судьей.

В уголовно-процессуальном праве исторически сформировались две теории разделения компетенции между присяжными и председательствующим судьей. Первая теория, общеизвестная и наиболее распространенная, за-

\footnotetext{
Определение Судебной коллегии по уголовным делам Верховного Суда РФ от 07.06.2006 № 26-о06-4сп // СПС «КонсультантПлюс».

4 Определение Судебной коллегии по уголовным делам Верховного Суда РФ от 04.05.2012 № 41-О12-24сп // СПС «КонсультантПлюс».
} 
ключается в том, что судьи решают вопросы права, а присяжные - вопросы факта (de jure respondent judices, de facto juratores).

В 1860-х гг. теория фракта и права подверглась серьезной критике в германской литературе. Глазер, Гнейст, Гейнце, Бар, Гуго-Мейер доказывали ее несоответствие задачам правосудия и сущности института присяжных заседателей. В результате была предложена другая теория, получившая господство в германском законодательстве того периода, - виновности и наказания. Согласно ей присяжные заседатели разрешают вопрос о виновности в полном его объеме как со стороны фактической, так и со стороны правовой, а коронные судьи применяют к признанной виновности установленное наказание и вместе с тем решают те процессуальные вопросы, которые возникают при рассмотрении дела 5 .

Основные аргументы сторонников теории виновности и наказания сводятся к следующему: 1) вопрос о виновности подсудимого не может быть отнесен только к фрактическим вопросам, поскольку представляет собой результат нравственно-правовой оценки присяжными заседателями деяния подсудимого, которое они признали доказанным;

2) во многих случаях деление на факт и право просто невозможно: немало таких преступлений, где нельзя рассуждать о факте, не рассуждая о праве, или где, наоборот, нельзя признать виновность без возможности свободно вникнуть в фактическую сторону дела 6 .

Среди современных исследователей суда присяжных сторонниками теории виновности и наказания являются Л.М. Карнозова, Г.Н. Борзенков, М.В. Немытина, С.А. Пашин и др.

Так, Л.М. Карнозова относит фракты, которые устанавливаются присяжными заседателями, не просто к фактам реальной жизни, а к юридически значимым представлениям об исследованных событиях и заключает, что в суде присяжных идет речь не о разделении факта и права, а о разделении сфер, где требуются специальные юридические знания и где они не требуются ${ }^{7}$. Она подчеркивает, что

Насонов С.А., Ярош С.М. Вердикт присяжных заседателей. М., 2003. С. 61-62.

6 См.: Муравьев Н.В. Из прошлой деятельности. СПб., 1900. Т. 1. С. 221 ; Гуэ-Глунек. О суде присяжных. СПб., 1865. С. 27-28 ; Щегловитов И.О. О постановке вопросов на суде присяжных // Юрид. вестник. Издание Моск. юрид. общества. 1888. № 5 . С. 52.

Карнозова Л.М. Возрожденный суд присяжных: замысел и проблемы становления. М., 2000. С. 250-251. «...если присяжные решают вопрос о виновности, они... решают вопрос правовой» ${ }^{8}$.

Поддерживает в своих рассуждениях Л.М. Карнозову и Г.Н. Борзенков: «Требование четкого отграничения вопросов факта от вопросов права практически неосуществимо. Возьмем основную триаду вопросов, подлежащих разрешению коллегией присяжных заседателей... Каждый из поставленных вопросов является одновременно и вопросом факта, и вопросом права. Что такое "соответствующее деяние", как не конкретное преступление, предусмотренное законом? И как решить, "имело ли оно место" и совершил ли его подсудимый, если не путем сопоставления содеянного с признаками конкретного состава преступления?» ${ }^{9}$.

М.В. Немытина отмечает, что «...нельзя направить практику по такому пути, при котором судьи бы занялись “переводом" с юридического языка на общеупотребительный принятых в законе понятий и определений ${ }^{10}$. Она видит два пути решения данной проблемы: 1) более детально с учетом теории уголовного права и процесса, практики применения определить, какие юридические категории понятны присяжным заседателям, а какие нет, какие могут вызвать у них противоречивое толкование, то есть дифференцированный подход; 2) ввести в уголовно-процессуальный закон норму, предоставляющую присяжным заседателям право разрешать вопрос о виновности подсудимого во всем его объеме, по существенным признакам состава преступления, как фактическим, так и правовым ${ }^{11}$.

C.A. Пашин полагает, что «...признавая за присяжными заседателями роль установителей фактов, Верховный Суд отнимает у них право устанавливать важные для дела юридические фракты. Отсюда проистекают парадоксальные запреты на постановку перед присяжными заседателями вопросов о намерениях подсудимого, о мотивах его действий, о состоянии аффректа, а также практика расчленения вопросов о виновности на составляющие, по поводу которых высказываются присяжные заседатели, и элементы, констатируемые судьей по собственному разумению и почину...

\footnotetext{
Карнозова Л.М. Уголовная юстиция и гражданское общество. Опыт парадигмального анализа. М., 2010. C.333.

9 Борзенков Г.Н. Суд присяжных и уголовный закон // Вестник МГУ. Серия «Право». 1994. № 4. С. 36.

10 Немытина М.В. Российский суд присяжных. М., 1995. C. 84.

11 Немытина М.В. Указ. соч. С. 84.
} 
В результате подобных манипуляций приговор суда с участием присяжных заседателей представляет собой причудливый симбиоз мнения присяжных заседателей о фрактах, которые их заставляют устанавливать в терминологии "виновности" и мнения судьи о виновности, к которому он приходит помимо точного смысла вердикта» ${ }^{12}$. В связи с этим С.А. Пашин предлагает ставить вопросы присяжным заседателям «в формулировках закона», например «Виновен ли подсудимый И.И. Иванов в убийстве с особой жестокостью?» ${ }^{13}$.

Проблема пределов судебного разбирательства в суде присяжных была характерна и для дореволюционного суда присяжных в России. Согласно ст. 760 Устава уголовного судопроизводства России «...в делах, решаемых с участием присяжных заседателей, предлагаемые им вопросы составляются в общеупотребительных выражениях, по существенным признакам преступления и виновности подсудимого, а не в виде принятых в законе определений» ${ }^{14}$. В первые годы деятельности суда присяжных кассационная инстанция (Сенат) своими многочисленными решениями поддерживала обязательность неукоснительного выполнения этой нормы. В результате, как указывал известный русский юрист С. Хрулев, «...такое требование закона и направление кассационной практики привело к тому, что многие общепонятные определения и термины были изгнаны из практики судов и заменены выражениями хотя и "общеупотребительными", но не всем понятными (например, слова “кража”, "украл”, “изнасиловал” заменялись выражениями "тайное похищение”, “тайно похитил”, “совокупился против ее воли, несмотря на ее сопротивление")» ${ }^{15}$.

Однако в дальнейшем Сенат изменил свою позицию о том, что в вопросах присяжным не должны встречаться выражения, употребляемые в законе. Как отмечал И.Я. Фойницкий, кассационная практика стала различать «между такими выражениями общепонятные и специальные, допуская первые и устраняя вторые». К первым причислялись: умысел, намерение, необходимое пособниче-

12 Пашин С.А. Становление правосудия. М. : Р. Валент, 2011. C. $272-273$.

13 Пашин С.А. Указ. соч. С. 278.

14 Устав уголовного судопроизводства. С алфавитным указателем, составленным присяжными поверенными М.В. Беренштамом и В.Н. Новиковым. СПб., 1908. C. 155 .

15 Хрулев С. Суд присяжных : Очерк деятельности судов и судебных порядков. СПб., 1886. С. 173. ство, случайная ошибка, похищение и т.п., а ко вторым - растрата, покушение, приготовление, поджог, грабеж, взлом и т.п. ${ }^{16}$ Таким образом, возникающие у судей трудности при формулировании вопросов были хотя и не полностью, но все же разрешены.

В связи с этим представляется, что подобным образом можно было бы разрешить проблемы при постановке вопросов перед присяжными и в современном российском уголовно-процессуальном законодательстве. Тем более что в практике производства в суде присяжных данный подход уже наметился.

Так, оставляя без изменения приговор, Верховный Суд РФ указал следующее: «Вопросы поставлены в понятных присяжным заседателям формулировках, с соблюдением требований ст. 339 УПК РФ.

Юридический термин "разбой” в вопросах № 11, 12, 15, 18 не использовался. Что касается терминов "нападение", "насилие, опасное для жизни и здоровья”, включенных в эти вопросы, то при обращении с напутственным словом председательствующий разъяснил присяжным заседателям значение этих несложных для понимания и общеупотребляемых понятий (выделено мной. - С.Н.). За их дополнительным разъяснением присяжные заседатели к председательствующему в порядке ст. 340 ч. 5 УПК РФ не обращались.

Поэтому следует признать, что и при формулировании вопросов № 11, 12, 15, 18 нарушений ст. 339 УПК РФ, влекущих отмену приговора, не допущено» ${ }^{17}$.

Представляется, что внесение процитированной позиции Верховного Суда РФ в качестве дополнительного положения в постановление Пленума Верховного Суда РФ от 22.11.2005 № 23 «О применении судами норм Уголовнопроцессуального кодекса Российской Федерации, регулирующих судопроизводство с участием присяжных заседателей» частично решит рассматриваемую проблему. Полное ее решение, на наш взгляд, возможно только в случае радикального изменения законодательства и судебной практики в направлении концепции виновности и наказания.

Таким образом, первая особенность пределов судебного разбирательства в суде с участием присяжных заседателей касается содержания обвинения и состоит в «разделе-

\footnotetext{
16 Фойницкий И.Я. Курс уголовного судопроизводства. СПб. : Альфа, 1996. Т. 2. С. 453-454.

17 Кассационное определение Судебной коллегии по уголовным делам Верховного Суда РФ от 18.01.2011 № 48-010-146сп // СПС «КонсультантПлюс».
} 
нии» обвинения на части (элементы), подлежащие исследованию (доказыванию) с участием присяжных заседателей и исследуемые только после вынесения вердикта.

С этим «разделением» обвинения связана и вторая особенность пределов судебного разбирательства в суде присяжных, обусловленная постановкой вопросов коллегии присяжных заседателей и составлением особого процессуального акта - вопросного листа.

Многие авторы отмечают, что вопросный лист является отражением содержания обвинения, поддерживаемого государственным обвинителем в судебном заседании с участием присяжных заседателей. По мнению М.В. Немытиной, вопросный лист - это «...изложенные в концентрированном виде в вопросной форме доказанные на основе обвинительного заключения в ходе судебного следствия и обоснованные в прениях сторон фрактические обстоятельства события преступления, причастности к его совершению подсудимого, виновности его, предлагаемые для ответа коллегии присяжных» ${ }^{18}$. С данной позицией можно согласиться, но с одной оговоркой - вопросный лист может включать в себя и фрактические обстоятельства позиции защиты.

Таким образом, на содержание вопросного листа в суде присяжных в полном объеме распространяются положения ст. 252 УПК РФ, регулирующей пределы судебного разбирательства.

Вместе с тем в практике производства в суде присяжных проявились несколько проблем, обусловленных соответствием вопросного листа требованиям пределов судебного разбирательства.

Первая из этих проблем вызвана тем, что нередко содержание обвинения, изложенного в основных вопросах вопросного листа, отличается от обвинения, изложенного в обвинительном заключении и поддерживаемого государственным обвинителем на этапе прений сторон в суде присяжных. Это несоответствие чаще всего проявляется в определенных формах.

Прежде всего, основные вопросы вопросного листа могут изменять обвинение путем иного изложения существенных элементов события преступления (времени, места, способа его совершения и др.).

Например, Судебная коллегия по уголовным делам Верховного Суда РФ отменила приговор Рязанского областного суда в отношении П., Т., К. и Ж., осужденных по п. «ж» ч. 2 ст. 105 УК РФ, и направила дело на новое рас-

\footnotetext{
18 Немытина М. В. Указ. соч. С. 73.
}

смотрение, указав: «...Из обвинительного заключения следует, что осужденные совершили убийство К.: 8 февраля 2002 г. около 20 час. сначала причинили ему телесные повреждения в квартире П. в деревне Романцево, затем - на берегу реки Оки возле гидроузла в селе Кузьминское, куда привезли в багажнике автомобиля, и его труп бросили на лед реки. Как видно из протокола судебного заседания, в своей речи в прениях государственный обвинитель, исходя из показаний ряда свидетелей, пришел к выводу, что К. приехал в деревню Романцево вечером к десяти - половине одиннадцатого вечера. Поэтому государственный обвинитель предложил уточнить время совершения преступления при формулировании вопросного листа. С учетом этого председательствующий в вопросном листе, а именно в основном вопросе № 1 о доказанности события преступления, время совершения преступления указал не то, которое значилось в обвинительном заключении, - “около 20 часов”, а другое - “после 22 часов". Такое изменение обвинения о времени совершения преступления ухудшило положение подсудимых, поскольку нарушило право на защиту. В частности, подсудимый К. вину в совершении убийства не признал, заявил о наличии у него алиби, пояснил, что около 20 час., т.е. в указанное в обвинительном заключении время совершения убийства, он в деревне Романцево не находился, а приехал туда лишь вечером в пятнадцать - двадцать минут одиннадцатого. Возражение адвоката в защиту К. о том, что изменение обвинения относительно времени совершения преступления ухудшает положение подсудимого, председательствующим в нарушение требований ст. 252 УПК РФ было отклонено» ${ }^{19}$.

Однако если подобное изменение обвинения не нарушает право подсудимого на защиту, Верховный Суд РФ не признает такое расхождение в формулировках вопросного листа и обвинительного заключения основанием к отмене приговора.

В частности, по делу С. и К. в кассационном определении Судебной коллегии по уголовным делам Верховного Суда РФ отмечено: «Действительно, в вопросах № 1 и № 2 содержится слово “заряженный”, в то время как в обвинительном заключении этого слова нет (в обвинительном заключении значится, что К. из предоставленного С. для убийства К-ца обреза произвел в туловище потерпевшего не

19 Кассационное определение Судебной коллегии по уголовным делам Верховного Суда РФ от 16.09.2003 № 6-кпо03-28сп // СПС «КонсультантПлюс». 
менее двух выстрелов). Между тем это не может быть расценено как нарушение статьи 252 УПК РФ, поскольку в формулировке вопросов не содержится, что К. либо С. зарядили обрез, т.е. за пределы обвинения судья не вышел, положение осужденных не ухудшил» ${ }^{20}$

Аналогичную позицию Верховный Суд РФ занял по делу Т. и К.: «Действительно, в обвинительном заключении речь идет о том, что “...Д. скончался по пути в больницу пос. <...>” В 1-м основном вопросе по данному деянию указано, что “...от указанного ранения он (Д.) скончался на месте". Данное отступление от текста обвинительного заключения не влияет на существо вопроса, на который дан утвердительный ответ, и не свидетельствует о нарушении судом положений ст. 339 ч. 1 УПК РФ»21.

Другая форма изменения обвинения основными вопросами вопросного листа состоит в фррагментации обвинения - неполном отражении в них всех обстоятельств вменяемого подсудимому деяния.

Например, в кассационном определении Судебной коллегии по уголовным делам Верховного Суда РФ по делу С. и Х. как на основание отмены приговора указывалось: «Из предъявленного органами предварительного расследования обвинения С. и Х. следует, что они обвинялись в разбойном нападении и убийстве Козловой Р.И., совершенном по предварительному сговору группой лиц.

Между тем в вопросном листе основной вопрос № 1 о доказанности или недоказанности события преступления и совершения конкретных деяний, имевших место 12 июля 2001 г., поставлен не в соответствии с предъявленным обвинением и позицией государственного обвинителя.

А именно: председательствующий судья при постановке вопроса № 1 не описал в нем все действия, которые по обвинению были совершены группой лиц по предварительному сговору, в частности не указал как преступные действия С. и Х., предшествующие посадке потерпевшей Козловой Р.И. в автомашину, так и роль Х., выступившего согласно обвинению в качестве организатора разбойного нападения на потерпевшую и ее убийства. Таким образом, основные вопросы № 2, 5 о доказанности или недоказанности участия С. и X. В

20 Кассационное определение Судебной коллегии по уголовным делам Верховного Суда РФ от 05.05.2005 № 58-о05-14сп // СПС «КонсультантПлюс».

21 Кассационное определение Судебной коллегии по уголовным делам Верховного Суда РФ от 19.03.2008 № 74-О07-64сп // СПС «КонсультантПлюс». совершении этих деяний с конкретизацией их действий в соответствии с предъявленным обвинением поставлены не были...» ${ }^{22}$.

Данное несоответствие может быть признано основанием для отмены приговора, даже если оно касается одного обстоятельства вменяемого деяния (или незначительного количества обстоятельств), если это обстоятельство является существенным элементом обвинения.

Так, отменяя оправдательный приговор по делу Р., Судебная коллегия по уголовным делам Верховного Суда РФ подчеркнула: «Из протокола судебного заседания усматривается, что государственный обвинитель предъявленное Р. обвинение поддержал. Вместе с тем в вопросном листе ни в первом вопросе, как того требует уголовно-процессуальный закон, ни в последующих вопросах не содержатся обстоятельства относительно содеянного, инкриминированного Р., связанные с тем, что Р. встречалась с оперативным сотрудником УБОП при УВД ПК Савиным А.А., которого она воспринимала как исполнителя преступления и с которым она обговорила условия совершения убийства потерпевших. За совершение этого преступления она пообещала Савину вознаграждение в сумме двух тысяч долларов США» ${ }^{23}$.

По делу С.Д. и С.А. Верховный Суд РФ отменил приговор, поскольку С.Д. вменялось, что он, помимо других действий, причинил потерпевшей странгуляционную борозду с признаками асфиксии, приведшей к бессознательному состоянию и коме, что расценивается как тяжкий вред здоровью. Однако «...на разрешение присяжных заседателей не был поставлен (в первом основном вопросе) вопрос о доказанности приведения С.Д. потерпевшей к бессознательному состоянию и коме» ${ }^{24}$.

Следующей формой нарушения пределов судебного разбирательства при формулировании основных вопросов в вопросном листе является постановка вопросов о виновности иных, кроме подсудимого, лиц. Такая ситуация на практике чаще всего возникает тогда, когда подсудимый утверждает, что оборонялся от нападения потерпевшего.

22 Кассационное определение Судебной коллегии по уголовным делам Верховного Суда РФ от 28.08.2002 № 7-кпо02-15сп // СПС «КонсультантПлюс».

23 Кассационное определение Судебной коллегии по уголовным делам Верховного Суда РФ от 15.06.2005 № 56-о05-40сп // СПС «КонсультантПлюс».

24 Кассационное определение Судебной коллегии по уголовным делам Верховного Суда РФ от 21.12.2005 № 81-о05-91сп // СПС «КонсультантПлюс». 
В кассационном определении Судебной коллегии по уголовным делам Верховного Суда РФ по делу К. среди оснований отмены приговора было указано: «Третий вопрос был поставлен в редакции, предложенный подсудимым К.: “Если на первый вопрос дан утвердительный ответ, то доказано ли, что перечисленные в нем действия совершил К. при следующих обстоятельствах: Погорелов Г.Д. схватил осколок бутылки и накинулся с ним на К., К. ударом ноги в пах выбил осколок бутылочного стекла из рук потерпевшего, поднял его с пола и нанес им множественные удары в различные части тела потерпевшего, потерпевший ударил К. рукой в грудь, К. уронил бутылку, схватил отвертку и нанес ею не менее 6 ударов в тело потерпевшего?". На этот вопрос присяжные заседатели... ответили единодушно: "Да, доказано". <...> По смыслу закона, поскольку разбирательство в суде производится только в отношении подсудимых, в вопросном листе недопустима постановка вопросов о виновности иных, кроме подсудимых, лиц» ${ }^{25}$.

Вместе с тем, если подобные вопросы поставлены без упоминания потерпевшего и не требуют какой-либо оценки его действий присяжными, их постановка, на наш взгляд, не будет нарушать пределы судебного разбирательства. В подобных случаях Верховный Суд РФ допускает постановку таких вопросов. Например, по делу П. в кассационном определении отмечалось, что «...данный вопрос был затронут в вопросном листе не в целях оценки действий потерпевшего С. и признания его виновным, а в связи с выяснением побудительных мотивов действий П., что уголовно-процессуальный закон не запрещает» ${ }^{26}$.

Второй блок проблем соответствия вопросного листа требованиям пределов судебного разбирательства обусловлен закрепленной в УПК РФ возможностью сторон ставить перед присяжными частные и альтернативные вопросы ${ }^{27}$.

Возможность постановки перед присяжными заседателями частных и альтернатив-

\footnotetext{
25 Кассационное определение Судебной коллегии по уголовным делам Верховного Суда РФ от 03.12.2002 № 4-кпо02-124сп // СПС «КонсультантПлюс».

26 Кассационное определение Судебной коллегии по уголовным делам Верховного Суда РФ от 24.02.2009 № 67-009-5сп // СПС «КонсультантПлюс».

27 В УПК РФ термин «альтернативный вопрос» не употребляется, однако он используется в определениях Верховного Суда РФ (например: кассационное определение Судебной коллегии по уголовным делам Верховного Суда РФ от 29.06.2005 № 66-о05-35сп // СПС «КонсультантПлюс»).
}

ных вопросов предусмотрена ч. 3 ст. 339 УПК РФ, где говорится о том, что после основного вопроса о виновности подсудимого могут ставиться частные вопросы о таких обстоятельствах, которые влияют на степень виновности либо изменяют ее характер, влекут за собой освобождение подсудимого от ответственности. В необходимых случаях отдельно ставятся также вопросы о степени осуществления преступного намерения, причинах, в силу которых деяние не было доведено до конца, степени и характере соучастия каждого из подсудимых в совершении преступления. Допустимы вопросы, позволяющие установить виновность подсудимого в совершении менее тяжкого преступления, если этим не ухудшается положение подсудимого и не нарушается его право на защиту.

Согласно ч. 2 ст. 338 УПК РФ судья не вправе отказать подсудимому или его защитнику в постановке вопросов о наличии по уголовному делу фактических обстоятельств, исключающих ответственность подсудимого за содеянное или влекущих за собой его ответственность за менее тяжкое преступление. Отказ председательствующего судьи стороне защиты в постановке таких вопросов влечет отмену приговора судом второй инстанции ${ }^{28}$.

Между тем альтернативный вопрос стороны защиты может изменить содержание обвинения самым существенным образом, затрагивая любые обстоятельства, подлежащие разрешению в вердикте присяжными заседателями.

Например, по делу К. присяжные заседатели «...не согласились с версией органов предварительного следствия о доказанности обвинения осужденных в том, что они бросили зажигательное устройство в квартиру потерпевших с целью лишения жизни Г. и покушения на лишение жизни Г.

Они признали доказанной позицию осужденных о том, что зажигательное устройство они бросили в квартиру с целью уничтожения имущества генерала Г., в результате чего возник пожар, в ходе которого было уничтожено имущество на общую сумму... Пожаром была повреждена квартира потерпевших, стоимость восстановительных работ в квартире составила.... В ходе тушения пожара Г. и... получили ожоги. От полученных повреждений Г.

28 См.: Кассационное определение Судебной коллегии по уголовным делам Верховного Суда РФ от 08.07.2004 № 32-о04-37сп // СПС «КонсультантПлюс». 
скончался» ${ }^{29}$. Очевидно, что здесь обвинение (как объект, так и объективная и субъективная стороны состава преступления) подверглось существенной корректировке.

Гарантией того, что постановка альтернативных (частных) вопросов не нарушит пределы судебного разбирательства, служат некоторые запреты, содержащиеся в ч. 2 ст. 338, ч. 3 ст. 339 УПК РФ.

Во-первых, постановка перед присяжными заседателями альтернативных (частных) вопросов допускается только в том случае, если о совершении менее тяжкого преступления (или об обстоятельствах, исключающих ответственность подсудимого за содеянное) давал показания подсудимый и на этом строилась позиция стороны защиты на протяжении всего судебного разбирательства. Это требование обеспечивает соблюдение права обвиняемого на защиту при постановке альтернативных вопросов.

Если подсудимый, оспаривая предъявленное ему обвинение, не указывал на совершение менее тяжкого преступления (или на обстоятельства, исключающие его ответственность за содеянное), альтернативные (частные) вопросы постановке не подлежат.

Так, по делу Д. Верховный Суд РФ указал: «Доводы осужденного Д. и адвоката Фрумкина М.Л. в жалобах о том, что судом необоснованно отказано стороне защиты в постановке перед присяжными заседателями вопросов об ответственности подсудимого за менее тяжкое преступление, а именно о доказанности и виновности Д. в совершении заранее не обещанного укрывательства убийства и разбойного нападения, являются несостоятельными, поскольку постановка указанных вопросов, согласно требованиям ч. 2 ст. 338 УПК РФ, предполагает наличие по уголовному делу фактических обстоятельств, исключающих ответственность подсудимого за содеянное или влекущих за собой его ответственность за менее тяжкое преступление.

Таких фрактических обстоятельств по данному уголовному делу не имелось, и сторона защиты на них не указывала.

Постановка указанных вопросов противоречила бы предъявленному обвинению, согласно которому Д. обвинялся в разбое и убийстве К. <...>

Кроме того, в случае отсутствия или недостаточности доказательств, присяжные заседатели могли вынести вердикт о недоказанно-

29 Кассационное определение Судебной коллегии по уголовным делам Верховного Суда РФ от 26.11.2008 № 64-О08-44сп // СПС «КонсультантПлюс». сти или невиновности Д. по предъявленному ему обвинению в разбое и убийстве.

Между тем присяжные заседатели единодушно признали Д. виновным в разбое и причинении смерти К.

Таким образом, следует признать, что у суда не имелось оснований для постановки вопросов, предложенных адвокатом Фрумкиным» ${ }^{30}$.

Во-вторых, председательствующий судья не вправе произвольно менять редакцию альтернативных (частных) вопросов, предложенных стороной защиты, в сторону, ухудшающую положение подсудимого, а также существенно изменять такую редакцию, включая в нее другие обстоятельства. Очевидно, что председательствующий судья вправе исключить из такого вопроса обстоятельства, не упоминавшиеся в судебном разбирательстве, заменить юридические термины на общеупотребительные, но иное редактирование альтернативных (частных) вопросов защиты будет противоречить закону.

Например, отменяя приговор по делу Ч., Верховный Суд РФ указал, что «...в судебном заседании подсудимый пояснил, что он один выстрел произвел вверх, а два - в опору линии электропередачи.

Адвокат в связи с данной позицией подсудимого в прениях говорил о попадании дробины в Д. и в голову М. в результате рикошета от опоры и при обсуждении сорормулированных председательствующим вопросов, подлежащих разрешению присяжными заседателями, предложил поставить альтернативный вопрос о наличии обстоятельства, исключающего ответственность подсудимого за содеянное или влекущего за собой его ответственность за менее тяжкое преступление, в следующей редакции: “Ч. вышел с ружьем, предупредил, чтобы все расходились, после чего произвел один выстрел в воздух и два выстрела в опору".

Однако председательствующий вопреки позиции защиты изменил вопрос по существу и... указал в девятом вопросе: “...производя два других выстрела, Ч. направил ружье в сторону опоры линии электропередачи у дороги, недалеко от которой стояла группа вышеназванных лиц, среди них были Д. и М.?” и тем самым ухудшил положение обвиняемого» ${ }^{31}$.

\footnotetext{
30 Кассационное определение Судебной коллегии по уголовным делам Верховного Суда РФ от 29.07.2010 № 19-О10-38сп // СПС «КонсультантПлюс».

31 Кассационное определение Судебной коллегии по уголовным делам Верховного Суда РФ от 03.08.2004 № 51-о04-61сп // СПС «КонсультантПлюс».
} 
Следующий блок проблем соответствия вопросного листа требованиям пределов судебного разбирательства обусловлен правом присяжных заседателей при вынесении вердикта признавать какие-либо обстоятельства недоказанными, т.е. изменять фрактическую сторону обвинения. Конструкция вопросного листа позволяет присяжным заседателям изменять фактическую сторону обвинения в направлении его сужения, путем исключения тех или иных обстоятельств из числа признанных доказанными. Каких-либо ограничений такого изменения обвинения законом не установлено, вследствие чего данное полномочие присяжных заседателей вызывало и вызывает определенное опасение у ряда авторов.

Анализируя сходное право присяжных по Уставу уголовного судопроизводства, И.Я. Фойницкий писал, что «...предоставление присяжным заседателям беспредельного права вводить в свои ответы ограничения и дополнения было бы существенным нарушением того коренного начала уголовного процесса, по которому никто не может быть признан виновным и подлежать наказанию за преступление, не рассматривающееся в надлежащем порядке судебного производства, что может иметь место при беспредельном праве присяжных на ограничение и особенно дополнение утвердительных или отрицательных ответов на поставленные вопросы» ${ }^{32}$.

На наш взгляд, ничем не ограниченное право присяжных заседателей признать недоказанными любые обстоятельства обвинения (как и все обвинение в целом) не создает опасности нарушения пределов судебного разбирательства, поскольку реализация присяжными этого права повлечет признание обвиняемого виновным в менее тяжком преступлении, т.е. улучшение его положения. Право на защиту обвиняемого в этой ситуации не будет нарушаться, т.к. новое обвинение будет основано на фактах, тождественных обстоятельствам, входившим в ранее предъявленное обвинение. Эти факты не будут новыми для подсудимого.

В соответствии с ч. 6 ст. 343 УПК РФ при вынесении вердикта «виновен» присяжные заседатели вправе изменить обвинение в сторону, благоприятную для подсудимого. Нарушение этого требования проявляется чаще всего в дополнении присяжными заседателями своих ответов указаниями на обстоятельства, о которых вопросы им не ставились.

32 Фойницкий И.Я. Курс уголовного судопроизводства. СПб. : Альфа, 1996. Т. 2. С. 477.
Так, по делу Ч. Верховный Суд РФ подчеркнул: «...при ответе на вопрос 3.2 о виновности Ч. в действиях, изложенных в предыдущих вопросах, присяжные заседатели указали: "Да, виновен в связи с причинением смерти потерпевшему", хотя вопрос о виновности Ч. в действиях, причинивших смерть С., не ставился. Таким образом, присяжные заседатели изменили суть обвинения Ч. в сторону, ухудшающую его положение» ${ }^{33}$.

Это нарушение пределов судебного разбирательства в суде присяжных вполне устранимо, поскольку председательствующий наделен правом проверки вердикта присяжных заседателей до его провозглашения. Найдя в вердикте суждения присяжных, выходящие за рамки поставленных перед ними вопросов, он вправе дать присяжным заседателям указание об устранении нарушения формы вердикта.

Третья особенность пределов судебного разбирательства в суде присяжных состоит в том, что формулировка и юридическая квалификация преступления в приговоре должны полностью соответствовать тем фактическим обстоятельствам, которые установлены вердиктом присяжных заседателей.

Анализ судебной практики позволяет выявить типичные случаи нарушения пределов судебного разбирательства применительно к этой их особенности в суде присяжных.

Прежде всего, пределы судебного разбирательства будут нарушены, если в приговоре суда существенно изменены установленные присяжными заседателями фрактические обстоятельства деяния, вменяемого подсудимому.

Например, Х. было предъявлено обвинение в совершении разбойного нападения и покушения на убийство в Москве 13 марта 2002 г. Однако в судебном заседании потерпевший по делу показал, что нападение на него было совершено 13 марта 2003 г. Свидетель Б. также давал показания о событиях 13 марта 2003 г. Подсудимый Х. был допрошен в суде о событиях, происшедших 13 марта 2003 г., а по предъявленному обвинению в совершении преступления 13 марта 2002 г. вообще допрошен не был и не давал никаких пояснений. Перед присяжными заседателями был поставлен вопрос о доказанности разбойного нападения и покушения на убийство, совершенных 13 марта 2002 г., на который дан утвердительный ответ. Однако по приговору суда X. был осужден за совершение преступления 13 марта 2003 г. От-

33 Кассационное определение Судебной коллегии по уголовным делам Верховного Суда РФ от 22.05.2008 № 68-О08-1сп // СПС «КонсультантПлюс». 
меняя указанный приговор, Верховный Суд РФ отметил: «В данном случае время совершения преступления указано не в соответствии с вердиктом коллегии присяжных заседателей. Однако вызвано это не технической ошибкой председательствующего по делу, а нарушением требований ч. 1 ст. 252 УПК РФ, так как в судебном заседании исследовались события, произошедшие 13 марта 2003 г.» ${ }^{34}$.

Необходимо подчеркнуть, что согласно ч. 1 ст. 348 УПК РФ оправдательный вердикт присяжных заседателей является обязательным для председательствующего судьи применительно ко всем аспектам обвинения, которое поддерживалось в судебном заседании государственным обвинителем. В случае вынесения присяжными заседателями обвинительного вердикта судья вправе не согласиться с фрактической стороной обвинения, установленной присяжными заседателями, однако при этом он обязан распустить коллегию присяжных и начать слушать дело заново (ч. 5 ст. 348 УПК РФ). Закон не предоставляет председательствующему судье права изменять в приговоре содержание обстоятельств деяния, установленных присяжными заседателями.

Следующей типичной ситуацией нарушения пределов судебного разбирательства после вынесения присяжными заседателями вердикта является незаконное расширение обвинения в приговоре по сравнению с вердиктом - как применительно к фактической стороне обвинения, так и к квалификации содеянного.

Это нарушение проявляется, во-первых, при указании в приговоре суда квалифицирующих признаков преступления, которые не соответствуют обстоятельствам, установленным вердиктом присяжных заседателей. Таким образом, данное нарушение пределов судебного разбирательства обусловлено неверной юридической интерпретацией фактов, установленных вердиктом присяжных заседателей.

Например, по делу Л., И. и В. Верховный Суд РФ указал: «Действия осужденных Л., И., B. по факту завладения имуществом С. суд квалифицировал правильно как преступление, предусмотренное ст. 158 УК РФ... как кража, то есть тайное хищение чужого имущества, совершенная с незаконным проникновением в жилище, в крупном размере.

В то же время ошибочным следует признать квалификацию действий осужденных в указанной части как кража, совершенная организованной группой. <..>>

Постановление Президиума Верховного Суда РФ от 05.10.2005 № 625-П05 // СПС «КонсультантПлюс».
Обстоятельств, свидетельствующих о совершении указанной кражи организованной группой (устойчивой группой лиц), в вердикте не установлено, не приведено их и в приговоре. <...>

В соответствии с вердиктом по указанному эпизоду Л., В., И. признаны виновными в том, что: “3 декабря 2008 года около 11 часов Л., В. и И. по предварительной договоренности, взломав при помощи гвоздодеров входную дверь, незаконно проникли в квартиру... и тайно похитили золотые ювелирные изделия... на общую сумму...".

То есть присяжными заседателями установлено, что в указанном преступлении участвовали Л., И. и В., заранее договорившиеся о совместном совершении преступлений.

При таких данных действия подсудимых по завладению 3 декабря 2008 года имуществом С. следует квалифицировать по ст. 158 ч. 3 п.п. “а”, “в” УК РФ... как кража, совершенная группой лиц по предварительному сговору, с незаконным проникновением в жилище, в крупном размере» ${ }^{35}$.

Во-вторых, рассматриваемое нарушение пределов судебного разбирательства в суде присяжных может быть обусловлено выводом судьи в приговоре о доказанности таких обстоятельств, которые были отвергнуты вердиктом присяжных либо о которых присяжным заседателям вообще не ставились вопросы (т.е. они не устанавливались присяжными).

Так, Г., И., О. и В. были осуждены приговором Пермского краевого суда от 29.04.2010 по п. «а» ч. 4 ст. 162 УК РФ за разбойное нападение на потерпевших Ш. и М. в магазине «Исток» и по п. «а» ч. 4 ст. 162 УК РФ за разбойное нападение на потерпевших Е. и В. в магазине «Золотая рыбка», совершенные с угрозой применения насилия, опасного для жизни и здоровья, с применением оружия и предмета, используемого в качестве оружия, с незаконным проникновением с помещение, совершенные организованной группой. Разбои совершены около 4 часов утра, магазины работали в круглосуточном режиме. В судебном заседании государственный обвинитель не поддержал квалификацию разбойных нападений по квалифицирующему признаку «с незаконным проникновением с помещение», поскольку подсудимые свободно входили в работающие магазины. Факт того, что Г., И., О. и В. совершали разбойные на-

\footnotetext{
35 Кассационное определение Судебной коллегии по уголовным делам Верховного Суда РФ от 04.07.2012 № 58-О12-32сп // СПС «КонсультантПлюс».
} 
падения, будучи в магазине, признан доказанным и присяжными заседателями. Вместе с тем ни позиция государственного обвинителя, ни содержание вердикта коллегии присяжных не учтены судом при постановлении приговора, который изменен Судебной коллегией по уголовным делам Верховного Суда РФ путем исключения из осуждения Г., И., О. и В. за оба преступления по п. «а» ч. 4 ст. 162 УК РФ квалифицирующего признака «с незаконным проникновением в помещение» ${ }^{36}$.

Вместе с тем от этого нарушения пределов судебного разбирательства следует отличать случаи установления судьей в приговоре обстоятельств, которые присяжные были не вправе устанавливать в вердикте вследствие разграничения компетенции между ними и профессиональным судьей. Согласно ч. 3 ст. 348 УПК РФ председательствующий квалифицирует содеянное подсудимым в соответствии с обвинительным вердиктом, а также установленными судом обстоятельствами, не подлежащими установлению присяжными заседателями и требующими собственно юридической оценки.

Нарушением пределов судебного разбирательства при вынесении судом приговора является также незаконное сужение обвинения в приговоре по сравнению с вердиктом применительно как к фактической стороне обвинения, так и к квалификации содеянного. Это нарушение закона чаще всего обусловлено неверной юридической интерпретацией фактов, установленных присяжными заседателями в вердикте.

В частности, отменяя приговор по делу М. и других, Верховный Суд РФ указал: «Как следует из приговора, при квалификации действий М., Х., Б., Х., Ю., П., М. по хищению нефти, которые установлены вердиктом присяжных заседателей, суд исключил совершение этих преступлений "организованной группой”, признав наличие в них квалифицирующего признака "группой лиц по предварительному сговору”.

Между тем присяжные заседатели, признав недоказанным существование преступного сообщества (преступной организации) и исключив из вердикта действия, свидетельствующие о совершении деяний в составе преступного сообщества (преступной организации), в то же время при ответах на вопросы относительно конкретных эпизодов преступных посягательств установили наличие обсто-

\footnotetext{
36 Кассационное определение Судебной коллегии по уголовным делам Верховного Суда РФ от 22.09.2010 № 44-О10-67сп // СПС «КонсультантПлюс».
}

ятельств, на которые правильно обращается внимание в кассационном представлении.

Так, присяжные заседатели установили 17 фактов посягательств на объекты нефтедобывающей сферы, которые совершались в течение продолжительного периода (с января по август 2006 года) группой лиц с постоянным составом участников в большинстве эпизодов преступных действий.

В частности, как следует из вердикта, X. участвовал в совершении преступлений, состоящих из 16 фактов посягательств, М. -15, Х. и Ю. -11 , П. и М. - 5, Б. -2 .

В вердикте также нашло отражение, что преступные действия по хищению нефти... совершались в ночное время, по единым схемам применительно к каждому месту отбора нефти... Из вердикта, кроме этого, следует, что каждый участник действовал в соответствии с отведенной ему ролью... Все эти и другие указанные государственным обвинителем в представлении обстоятельства суд не оценил в приговоре в совокупности между собой и во взаимосвязи с положениями частей 3 и 5 статьи 35 УК РФ, хотя они вытекали из вердикта и соответствовали содержанию предъявленного обвинения.

Изложенное выше, таким образом, свидетельствует о том, что решение суда первой инстанции в отношении М., Х., Б., Х., Ю., П., М. относительно конкретной роли каждого в содеянном и наличия в их действиях признаков организованной группы является необоснованным» ${ }^{37}$.

Другой фрормой незаконного сужения обвинения в приговоре суда по сравнению с вердиктом присяжных заседателей является исключение судом из обвинения в приговоре тех эпизодов, от которых государственный обвинитель отказался на этапе обсуждения вердикта присяжных заседателей.

Как указал Верховный Суд РФ в кассационном определении по делу Ч. иЧ., «по смыслу закона, в соответствии со ст. 246 УПК РФ при обсуждении последствий обвинительного вердикта государственный обвинитель не вправе отказаться от обвинения либо изменить его, поскольку таким правом он может воспользоваться лишь до удаления коллегии присяжных заседателей в совещательную комнату» ${ }^{38}$.

\footnotetext{
Кассационное определение Судебной коллегии по уголовным делам Верховного Суда РФ от 15.02.2011 № 47-О10-74сп // СПС «КонсультантПлюс».

38 Кассационное определение Судебной коллегии по уголовным делам Верховного Суда РФ от 22.05.2008 № 68-О08-1сп // СПС «КонсультантПлюс».
} 
Такая позиция Верховного Суда РФ основана на ч. 4 ст. 347 УПК РФ, в силу которой сторонам запрещается ставить под сомнение правильность обвинительного вердикта, вынесенного присяжными заседателями.

Вместе с тем законодательство предусматривает и случаи законного сужения обвинения в приговоре суда по сравнению с вердиктом присяжных заседателей. Согласно ч. 4 ст. 348 УПК РФ обвинительный вердикт коллегии присяжных заседателей не препятствует постановлению оправдательного приговора, если председательствующий признает, что деяние подсудимого не содержит признаков преступления. Данное положение применимо как ко всем обстоятельствам обвинения, признанным доказанными присяжными заседателями, так и к отдельным из них.

В случае установления судами вышестоящих инстанций нарушения пределов судеб- ного разбирательства, допущенных после вынесения присяжными заседателями вердикта, приговор может быть отменен с направлением уголовного дела на новое судебное разбирательство с этапа обсуждения последствий вердикта присяжных заседателей. На наш взгляд, суд апелляционной инстанции полномочен самостоятельно исправить нарушения пределов судебного разбирательства последней группы.

Таким образом, требования пределов судебного разбирательства являются важнейшей процессуальной гарантией, обеспечивающей не только права подсудимого, но и правосудность выносимого присяжными заседателями вердикта, а также законность приговора суда. Именно поэтому необходима ориентация судебной практики на более строгое соблюдение этого общего условия в суде с участием присяжных заседателей.

\section{Библиография:}

1. Борзенков Г.Н. Суд присяжных и уголовный закон // Вестник МГУ. Серия «Право». - 1994. № 4.

2. Гуэ-Глунек. О суде присяжных. - СПб., 1865.

3. Карнозова Л.М. Возрожденный суд присяжных: замысел и проблемы становления. - М., 2000.

4. Карнозова Л.М. Уголовная юстиция и гражданское общество. Опыт парадигмального анализа. - М., 2010.

5. Муравьев Н.В. Из прошлой деятельности. - Т. 1. - СПб., 1900.

6. Насонов С.А., Ярош С.М. Вердикт присяжных заседателей. - М., 2003.

7. Немытина М.В. Российский суд присяжных. - М., 1995.

8. Пашин С.А. Становление правосудия. - М., 2011.

9. Хрулев С. Суд присяжных : Очерк деятельности судов и судебных порядков. - СПб., 1886.

10. Фойницкий И.Я. Курс уголовного судопроизводства. - Т. 2. - СПб., 1996.

\section{References:}

1. Borzenkov G.N. Sud prisyazhnykh i ugolovnyi zakon // Vestnik MGU. Seriya «Pravo». - 1994. № 4.

2. Gue-Glunek. O sude prisyazhnykh. - SPb., 1865.

3. Karnozova L.M. Vozrozhdennyi sud prnsyazhnykh: zamysel i nroblemy stanovlennya. - M., 2000.

4. Karnozova L.M. Ugolovnaya yustitsiya i grazhdanskoe obshchestvo. Opyt paradigmal'nogo analiza. - M., 2010.

5. Murav'ev N.V. Iz proshloi deyatel'nosti. - T. 1. - SPb., 1900.

6. Nasonov S.A., Yarosh S.M. Verdikt prisyazhnykh zasedatelei. - M., 2003.

7. Nemytina M.V. Rossiiskii sud prisyazhnykh. - M., 1995.

8. Pashin S.A. Stanovlenie pravosudiya. - M., 2011.

9. Khrulev S. Sud prisyazhnykh : Ocherk deyatel'nosti sudov i sudebnykh poryadkov. - SPb., 1886.

10. Foinitskii I.Ya. Kurs ugolovnogo sudoproizvodstva. - T. 2. - SPb., 1996. 